\title{
DIGITAL TRANSFORMATION IN PRIVATE BRAZILIAN HIGHER EDUCATION INSTITUTIONS: PRE-CORONAVIRUS BASELINE
}

\author{
FRANCISCO D. S. LUNA ${ }^{1}$ \\ (iD) https://orcid.org/0000-0002-9249-0339 \\ VIVALDO J. BRETERNITZ \\ (D) https://orcid.org/0000-0001-8604-2276
}

To cite this paper: Luna, F. D. S., \& Breternitz, V. J. (2021). Digital transformation in private Brazilian higher education institutions: Pre-coronavirus baseline. Revista de Administração Mackenzie, 22 (6), 1-31. doi:10.1590/1678-6971/eRAMD210127

Submission: Apr. 12, 2021. Acceptance: Sept. 10, 2021.

\footnotetext{
University of São Paulo (USP), São Paulo, SP, Brazil.

2 Mackenzie Presbyterian University (UPM), São Paulo, SP, Brazil.
}

\section{(c) $\mathrm{BY}$}




\section{ABSTRACT}

Purpose: To present the planning for the digital transformation of Brazilian higher education institutions (HEI) and to measure their degree of digital mastery, according to Westerman, Calméjane, Bonnet, Ferraris, and McAfee (2011).

Originality/value: Some studies evaluate digital transformation and/or the degree of digital mastery carried out in HEI individually. However, those that assess them comparatively have not been identified, allowing to draw a baseline to assist managers in benchmarking processes.

Design/methodology/approach: It is an exploratory, qualitative research, with field study, in which the secondary data were obtained through bibliographic and documentary sources and the primary data through semi-structured interviews. For this purpose, representatives of ten private HEI were interviewed using an instrument consisting of a script of questions. The content was analyzed according to the model of Bardin (2011) and supported by the tool Iramuteq. The findings served as an input for completing the digital mastery questionnaires.

Findings: Elements identified in the research refer to the fact that the evaluated HEI have good maturity in their digital transformation processes. Such allegations could be verified from the evaluation of digital mastery, which found that most institutions have a good level of digitalization and that, despite having some limitations related to the development of digital and leadership skills, can be considered digital masters.

\section{KEYWORDS}

Digital transformation. Higher education institution. Digital mastery. IT governance. Technology. 


\section{INTRODUCTION}

Regarding technology, the current environment of companies has been going through a process of deep changes arising from numerous factors, including a society that aspires to have a more practical and interconnected life. There are companies seeking to reduce costs of operational processes and improve efficiency; and there is the government, that encourages innovation and entrepreneurship as a way to improve integration into the global business environment to promote economic, social, and cultural development (Schwab, 2016; Rogers, 2017; Westerman, Bonnet, \& McAffe, 2016).

As for digital transformation, specifically, a widespread concept for such changes, it reflects the current moment of organizations and is supported by drivers and enablers (Schwab, 2016; McKinsey, 2016). When properly implemented, digital transformation can coordinate what is available in the company, leading to a better user or customer experience compared to solutions available on the market. Normally, such drivers and enablers are responses to objectives defined in the company's strategic plan, leading to a series of established tasks and projects, including implementing a new system, enabling customization, and improving one or more processes.

Higher education institutions (HEI) and other organizations face challenges and take advantage of opportunities created or brought by new technologies. According to data from Hoper (2018), referring to the private network of the higher education sector, in 2018, the number of enrollments for on-site courses decreased by $3.4 \%$ compared to 2017 and by $6.65 \%$ compared to 2015. Referring to the model of distance learning (EaD), the enrollment rate was reversed in 2018, increasing in $18.4 \%$ compared to 2017 and in $48.8 \%$ compared to 2015 .

According to data from the Instituto Nacional de Estudos e Pesquisas Educacionais Anísio Teixeira - Inep (Brazilian National Institute of Educational Studies and Research) (2020), referring to the 2018 census, Brazil has 2,537 HEI, 299 of which are public institutions and 2,238 are private (Hoper, 2018). Of the private institutions, more than $63 \%$ have less than 1,000 students, while only $5.8 \%$ have more than eight thousand students (Hoper, 2018), which shows that this is a very granular market. Davel (2018) states that "these institutions are the most vulnerable in the current scenario, as it is difficult to observe an economic balance in educational enterprises with a number of students of less than 1,200 undergraduates". 
To meet this demand, which has been showing a high growth, especially in the last decade, many institutions were created, driven by the distance learning model and the increase in credit for student finance.

Regarding distance learning, specifically, Brazilian Decree no. 9,057, published in the Diário Oficial da União (DOU) on May 25, 2017, establishes new rules for creating and offering new courses from elementary to higher education. Clause 2, article 11, chapter 3, states: "The accreditation of a higher education institution is allowed to offer exclusively the lato sensu graduate and postgraduate courses in the distance modality" (Decreto n. 9.057, 2017, p. 4, our translation). The aforementioned Decree also abolished the obligation for higher education institutions to maintain on-site courses, a requirement for being able to offer distance education, which allowed them, from then on, to specialize in distance learning, thus, bringing greater flexibility to the sector, increasing competition and putting pressure on well-established institutions (Carvalho, 2017).

According to Palhares (2018, p. A14, our translation), based on data from Inep, in 2007, distance learning "represented $7 \%$ of graduate enrollments. In 2017, it started to serve 1.7 million students - which represents $21.2 \%$ of the country's graduates [...], and in undergraduate courses, the modality already has $46.8 \%$ of the total number of students".

Based on Instituto Brasileiro de Geografia e Estatística (IBGE) (Brazilian Institute of Geography and Statistics) data, as of the second half of 2014, the Brazilian economy went into recession. Notably, from the first quarter of 2015, we had negative results for ten consecutive quarters. The improvement only started to emerge in the third quarter of 2017, when the quarterly gross domestic product (GDP) stopped being negative. In addition, this reduction in economic activity was reflected in the higher education market, since economic recession leads to unemployment and affects families' financial situation, thus, minimizing the capacity to invest in education (IBGE, 2020).

The latest household budget survey conducted with 57,920 families in Brazil (IBGE, 2019) pointed out that education accounts for only $4.7 \%$ of household consumption expenditures, while housing expenditure accounts for $36.6 \%$ and expenditure on food and transport, in turn, account for around $18 \%$.

Another factor that affected the higher education sector was the reduction in government incentives to Fundo de Financiamento Estudantil (FIES) (Brazilian Student Financing Fund), as student credit had been one of the factors that had been actively boosting the Brazilian higher education market. Many HEI were created to serve this audience, and many of them relied 
heavily on this funding. Koike (2018) evidences this fact by stating that about $40 \%$ of university students with on-site graduations in the country had FIES four years ago. In some educational institutions, especially in smaller ones, this percentage reached $70 \%$, and it is not by chance that several of them are breaking down.

It is noticed that the aforementioned factors directly affect the ability of colleges and universities to generate income and increase pressure on the effectiveness of strategies to ensure loyalty and retain the students. Thus, any information that may indicate to the institution the possibility of its students dropping out will become valuable, or even any other information about the processes and systems that generate greater engagement. Digital transformation in HEI is, therefore, necessary and urgent (Bridgstock, 2016; Khalid et al., 2018).

This scenario led to the definition of the following question for investigation:

- Are Brazilian private HEI prepared in their digital transformation process and, consequently, have the IT tools and processes that help them to achieve the results, or does their lack of preparation inhibit their growth?

\section{DIGITAL TRANSFORMATION, DRIVERS, ENABLERS, AND MEGATRENDS}

According to the Initiative for Digital Transformation (IDT, 2015, p. 3), "digital transformation describes a process of organizational change that leads to the application and implementation of digital technology". In a survey conducted by the IDT, respondents (81 IT executives from different regions of the world) agreed that there is still a large gap between demand and availability of knowledge. According to survey data, $73 \%$ of respondents said that excellent data analysis skills are essential for a company's digital transformation. However, only $39 \%$ of respondents said they have them (IDT, 2015).

In 2017, the Associação Brasileira das Empresas de Software (Brazilian Association of Software Companies) released data from its survey on panorama and trends in the use of software. According to this Brazilian research, most of the IT managers of the companies evaluated had digital transformation as the central theme of their actions. Also, according to the research mentioned above, "CIOs will focus their investments primarily on business 
initiatives focused on improving company processes, reducing costs and increasing organizational efficiency" (Abes, 2017, p. 21).

However, contrary to popular belief, digital transformation affects not only large companies or early adopters of new technologies, it is present in the daily lives of companies of all sizes, public or private. Anyone who thinks they are not affected by this transformation is mistaken (Harvard Business Review Analytics Services, 2015).

In 2015, the World Economic Forum (WEF) promoted a survey with more than 800 technology professionals, when 21 emerging technologies were presented. When asked when they believed that these technologies would become widely used globally, the answers ranged from "it has already happened" to "it will never happen". If it were viable, there would already be a trigger that would clearly represent this change (WEF, 2015).

Figure 2.1 shows the timeline of the technologies evaluated, indicating the moment when most respondents believed that the inflection point (trigger) would occur.

\section{(Figure 2.1)}

TIMELINE INDICATING THE MOMENT WHEN MOST RESPONDENTS BELIEVED THAT THE INFLECTION POINT (TRIGGER) WOULD OCCUR

\begin{tabular}{|c|c|c|c|c|c|c|c|}
\hline 2018 & 2021 & 2022 & 2023 & 2024 & 2025 & 2026 & 2027 \\
\hline \multirow[t]{2}{*}{$\begin{array}{l}\text { - Storage } \\
\text { for All }\end{array}$} & \multirow[t]{2}{*}{$\begin{array}{l}\text { - Robot } \\
\text { and } \\
\text { Services }\end{array}$} & $\begin{array}{l}\text { - The Internet of } \\
\text { and for Things } \\
\text { - Wearable } \\
\text { Internet } \\
\text { - 3D Printing and } \\
\text { Manufacturing }\end{array}$ & $\begin{array}{l}\text { - Implantable } \\
\text { Tecnologies } \\
\text { - Big Data for } \\
\text { Decisions } \\
\text { - Vision as the } \\
\text { New Interface } \\
\text { - Our Digital } \\
\text { Presence } \\
\text { - Governments } \\
\text { and the } \\
\text { Blockchain } \\
\text { - A } \\
\text { Supercomputer } \\
\text { in Your Pocket }\end{array}$ & $\begin{array}{l}\text {-3D Printing } \\
\text { and Human } \\
\text { Health } \\
\text { - The } \\
\text { Connected } \\
\text { Home }\end{array}$ & $\begin{array}{l}\text { - 3D Printing } \\
\text { and } \\
\text { Consumer } \\
\text { Products } \\
\text { - All and } \\
\text { White-Collar } \\
\text { Jobs } \\
\text { - The Sharing } \\
\text { Economy }\end{array}$ & $\begin{array}{l}\text { - Driverless } \\
\text { Cars } \\
\text { - Al and } \\
\text { Decision- } \\
\text { Making } \\
\text { - Smart } \\
\text { Cities }\end{array}$ & \multirow[t]{2}{*}{$\begin{array}{l}\text { - Bitcoit } \\
\text { and the } \\
\text { Blockchain }\end{array}$} \\
\hline & & & Source: WEF & $(2015$, p. 6). & & & \\
\hline
\end{tabular}

These inflection points are part of global social change and, therefore, will affect the functioning of universities and the professional training profile of students, a process caused mainly by digital transformation. 
The profile of the professionals of the future is the subject of frequent discussions. Richard Susskind and Daniel Susskind (2015) elaborated their views on how technology should change the needs or abilities of certain professional activities. They mentioned two possible futures for the industry: first, transforming and improving efficiency through the development of new skills by professionals and interaction with technical tools; second, when technology would replace work. The long-term trend of the latter is prevalent, which has generated a debate on how to train future professionals to adapt to this new situation (Susskind \& Susskind, 2015).

In this context, the growing dependence on technology tools to improve the business processes of organizations, both regarding maintaining their modus operandi and the feasibility of strategic objectives, enabling better monitoring, measurement, and security of processes involving IT (Brodbeck $\&$ Musse, 2014) and shedding light on IT governance, a topic that has been gaining a lot of visibility (Bianchi, Sousa, \& Pereira, 2017).

According to Mansur (2007), as investors changed their behavior and demanded that company CEOs have greater control and predictability over the reported numbers, the need for IT governance increased, which occurred in the 1990s. However, this activity was exacerbated by the "millennium bug", which caused people to invest in IT equipment and controls, a rare fact in the history of technology.

To help managers seek better control and effectiveness in IT processes, protect the company from potential operational risks, and improve the efficiency of product delivery to customers, the Information Systems Audit and Control Association (Isaca) has established a series of guidelines. It is noteworthy that Isaca's objective (s. d. (a)) is "to help business technology professionals and their companies around the world realize the positive potential of technology"; purpose achieved by some frameworks, patterns, and models that it maintains, among which the following stand out:

- Control Objectives for Information and Related Technologies (Cobit): they provide various tools, resources, and guidelines for IT governance and management (Isaca, s.d. (b));

- The Risk IT Framework - complementary to Cobit: it supports corporations in managing and controlling their IT risks (Isaca, s.d. (b)).

The characteristics of companies that implement technical tools and apply them to business processes to maximize results are called digital mastery (Westerman, Calméjane, Bonnet, Ferraris, \& McAfee, 2011). 
Digital masters stand out in two critical dimensions: "what about technology (what we call digital capabilities) and how to lead change (what we call leadership capabilities)" (Westerman et al., 2016, p. 27, italics in the original).

Digital capabilities are associated with using technology to improve products, interactions, and results, not as a tool but as a bridge to strategic goals. Leadership capabilities are related to the commitment of organizations and leaders and the improvement of the corporate culture to develop technical solutions that meet the company's needs (Westerman et al., 2016).

Some articles seek to draw a relationship between the digital capabilities of a HEI and the results. Rodrigues (2021) points out that numerous HEI are exploring technological innovations to adapt to the new demands and needs of their academic community. Santinello, Costa, and Santos (2020) also identify the implementation of technological tools as a response to aspirations arising from the transformation of society. It is corroborated even by Rodrigues $(2019$, p. 2), who points out that "modern society values HEI with a higher level of digitization, given that they consider education through technology to be essential for their professional future, not valuing those institutions that do not have higher levels of technological development than those they use".

Other works justify that the implementation of technology improves the processes of the HEI and, consequently, the quality. Kenski, Medeiros, and Ordéas (2019, p. 150) reflect on the need for Brazilian HEI to make changes in their educational process based on technology. They conclude that not observing the role of digital technologies in the teaching and learning process implies the maintenance of the anachronism of educational methods concerning contemporary reality, which is reflected in the low quality of the education and, consequently, in precarious professional training. Araújo and Gouveia (2020) reinforce the previous point and add that the ubiquity in the use of technologies facilitates the teaching/learning process and the relationship between student and teacher, allowing the development of new skills and competencies.

\section{METHODOLOGICAL PROCEDURES}

To measure the degree of digital mastery and understand how the digital transformation of Brazilian private HEI planning was being prepared, according to the model proposed by Westerman et al. (2011), interviews with experts and interactions with the managers of some HEI were carried out, aiming to understand the initial question of our investigation, which is to find out 
whether private Brazilian HEI are prepared in their digital transformation process and, consequently, have IT tools and processes that help them achieve the results or if their unpreparedness inhibit their growth.

It was necessary to answer the questions raised through field research, considering the exploratory nature of the research. Therefore, among the authors' client base, some available HEI interested in participating in the discussion were selected. According to the model proposed by Inep (2009) (based on the number of students enrolled in on-site undergraduate courses), institutions were classified as small, medium, or large to determine the definition of qualified personnel.

Based on this classification, a priori, at least three interlocutors from three different HEI of each size were selected, so that at least nine people belonging to the executive level (manager or higher) were interviewed, professionals who understood the mission and vision of the HEI, the definition of system requirements or the realization of such implementations in the HEI; and had effective participation in the institution's decision-making process.

During the selection phase of HEI to participate in the interviews, between August and December 2019, 24 potential institutions that met the standards established for the research were analyzed. There were some disagreements regarding the planning mentioned in the previous paragraph; one of them was the enormous difficulty in finding small institutions, with a number of less than a thousand students, in São Paulo, because there was a large increase in the number of students in distance learning as a result of the facts mentioned above.

Finally, considering the difficulties in selecting small HEI, ten representatives of HEI were defined, being four medium-sized, five large, and one enormous. It is noteworthy that in the definition of Inep (2009), there is no "enormous" classification. Still, due to the difference in size concerning the other HEI interviewed, it was decided to create this classification to improve the analysis.

For formal reasons, all interviews were organized through an invitation via e-mail, to which the "research plan" and the "consent" document to be signed by the interviewee were attached.

Figure 3.1 was organized to arrange the information and maintain the data confidentiality, which presents the profile of the representatives of the HEI interviewed, the HEI' characteristics, the date, and the duration of the interviews. To perform the future comparison, a coding was created for each HEI, established as follows: 
- $\quad$ HEI = higher education institution.

- $01-10$ = sequential, from 1 to 10 .

- $\mathrm{M}, \mathrm{L}$, or $\mathrm{E}=$ medium, large or enormous.

As shown in Figure 3.1, the duration of the interviews varied a lot, sometimes due to the respondent's characteristics, sometimes due to the availability of time. The shortest interview lasted 50 minutes, while the two longest lasted 107 minutes and 108 minutes. The average duration of each interview was 79 minutes, and the total time was 789 minutes, equivalent to 13 hours and nine minutes. Nine interviews were conducted in HEI in the state of São Paulo and one in the state of Bahia, eight of which were private institutions and two were confessional institutions, that is, in institutions related to religious organizations. As shown in Figure 3.1, the position occupied by the interviewees was not standardized, which may have eventually led to different views on the same reality.

\section{(Figure 3.1)}

\section{PROFILE OF THE REPRESENTATIVES OF THE HEI INTERVIEWED, CHARACTERISTICS OF THE HEI AND MODALITY, DATE AND DURATION OF THE INTERVIEW}

\begin{tabular}{|c|c|c|c|c|c|c|c|c|}
\hline HEI & UF & $\begin{array}{l}\text { Interviewee } \\
\text { (position) }\end{array}$ & $\begin{array}{l}\text { Quantity } \\
\text { of } \\
\text { students }\end{array}$ & Size & Characteristics & Modality & $\begin{array}{l}\text { Duration } \\
\text { (min) }\end{array}$ & $\begin{array}{c}\text { Date } \\
\text { of the } \\
\text { interview }\end{array}$ \\
\hline HHHEI-01-L & $S P$ & $\begin{array}{l}\text { Business and } \\
\text { Process Manager }\end{array}$ & 12,000 & Large & Private & Presential & 86 & 08/15/19 \\
\hline HEHEI-OZ-M & $S P$ & $\begin{array}{l}\text { Senior Systems } \\
\text { Analyst }\end{array}$ & 3,000 & Medium & Private & Presential & 67 & 08/26/19 \\
\hline HEHEI-03-M & $S P$ & $\begin{array}{l}\text { Director of } \\
\text { Operations - COO }\end{array}$ & 2,350 & Medium & Private & Presential & 91 & 08/30/19 \\
\hline HEHEI-04-L & $S P$ & $\mathrm{ClO}$ & 17,000 & Large & Confessional & Presential & 107 & 09/12/19 \\
\hline HEHEI-05-M & SP & Vice Dean & 4,700 & Medium & Private & Presential & 59 & 09/20/19 \\
\hline HEHEI-06-E & $S P$ & ClO Brazil & 300,000 & Enormous & Private & Presential & 61 & 10/02/19 \\
\hline HEHEI-07-M & SP & Director & 4,500 & Medium & Private & Presential & 80 & 10/11/19 \\
\hline HEHEI-08-L & SP & Director & 42,000 & Large & Confessional & Presential & 50 & 11/07/19 \\
\hline HEHEI-09-L & SP & $\begin{array}{l}\text { Administrative / } \\
\text { Financial Director }\end{array}$ & 15,000 & Large & Private & Presential & 108 & 11/07/19 \\
\hline HEHEI-10-L & BA & $\begin{array}{l}\text { VP of Strategy, } \\
\text { Org, and } \\
\text { Technology }\end{array}$ & 25,000 & Large & Private & Skype & 80 & 12/12/19 \\
\hline
\end{tabular}


All interviews were semi-structured and recorded with the interviewee's consent. Overall, the interview process was soft, and the information obtained was very valuable in relation to the characteristics of the operation's management, strategy, and especially regarding technology.

For the analysis of the main data collected, the organizational model defined by Bardin (2011) was followed, which establishes the following organizational steps:

1) Pre-analysis based on an initial organization: in addition to intuition, a way to systematize the analysis model is sought and, based on it, the analysis plan is developed. According to Bardin (2011, p.124), the pre-analysis has three missions: "the choice of documents to be submitted for analysis; the formulation of hypotheses and objectives; and the elaboration of indicators that support the final interpretation". This step includes important aspects, such as: floating reading, document selection basis, reduction of ideas (sampling), and rules relevant to the use of documents;

2) Exploration of the material based on a preliminary understanding of the content: classifying, coding, and decomposing data and findings as a way of grouping analyses and findings;

3) Treatment of results, inference, and interpretation: from the previous steps, the researcher seeks the meaning of the relationships and groupings performed. In this step, the information must be processed in order to be meaningful.

To analyze the content of the material as a research source, the coding technique established by Bardin (2011) was applied, which includes three choices:

- Cutting: selection of units - words, phrases, or topics.

- Enumeration: choice of counting rules - word frequency, presence or absence, correlation, weighted frequency, intensity, direction, order, competition.

- Classification and aggregation: choice of categories - in blocks, according to related information and contexts.

To apply the text model, questionnaire, and multidimensional analysis proposed by Bardin (2011), the free tool Iramuteq (2020) was used, which allowed the performance of statistical analyzes on the body of the text regarding similarity analysis, blocks (grouping by type content), and word correlation. This technology was used to count and classify terms by generating tree diagrams. To verify the degree of development of each HEI analyzed in 
relation to digital transformation, after analyzing the content of the interviews, two questionnaires proposed by Westerman et al. (2016) were evaluated and answered are presented in figures 3.2 and 3.3. This procedure was used to ensure that the data for completing the questionnaire emerged from the interviews, preventing direct responses from respondents from distorting reality due to bias.

\section{(Figure 3.2)}

\section{QUESTIONNAIRE ON DIGITAL CAPABILITIES}

In which stage is your company in the training of digital capabilities?

Scale from 1 to 7

1 = totally disagree; 4 = indifferent; 7 = completely agree

We are using digital technologies (such as analytics, social media, mobile technologies, and embedded devices) to better understand our customers.

We use digital channels (online, social media, and mobile devices) for marketing our products and services.

We sell our products and services through digital channels.

We use digital channels to provide service to our customers.

Technology is enabling us to link operational processes (as well as direct customer contact) in new ways.

Our main processes are automated.

We have an integrated view of strategic, operational, and customer information.

We use analytics to make better operational decisions.

We use digital technologies to increase the performance or added value of our products and our services.

We launch new models based on digital technologies.

Final score

Source: Westerman et al. (2016, p. 272). 


\section{(Figure 3.3) \\ LEADERSHIP CAPABILITIES QUESTIONNAIRE}

In which stage is your company in the development of leadership capabilities?

Scale from 1 to 7

1 = totally disagree; 4 = indifferent; 7 = completely agree

Answers

The company's top management has a transformative view of our company's digital future.

The company's top and middle management have a common view about digital transformation.

There are opportunities for everyone in the company to take part in the conversation about digital transformation.

The company is promoting the cultural changes necessary for digital transformation.

The company is investing in the necessary digital expertise.

Digital initiatives are coordinated by breaking "barriers" such as functions or regions.

The roles and responsibilities for conducting digital initiatives are clearly defined.

Digital initiatives are measured against a common set of key performance indicators.

Business and IT leaders work together as partners.

The performance of the IT unit meets the company's needs.

Final score

Source: Westerman et al. (2016, p. 273).

As established by Westerman et al. 's model (2016, p. 272, our translation),

[...] scores for digital capabilities range from 10 to 70 . A score between 10 and 41 means your company is in the bottom half of the distribution, while a score between 42 and 70 puts you in the top half. For leadership skills, scores range from 10 to 70 . A score between 10 and 42 means that your company is on the left side of the distribution, while a score between 43 and 70 places it on the right. 
After obtaining the answers to all the questionnaires, one for each HEI, and their respective analyses, the HEI were classified according to the levels of digital mastery, as shown in Figure 3.4.

\section{(Figure 3.4) \\ CLASSIFICATION OF DIGITAL MASTERY LEVELS}

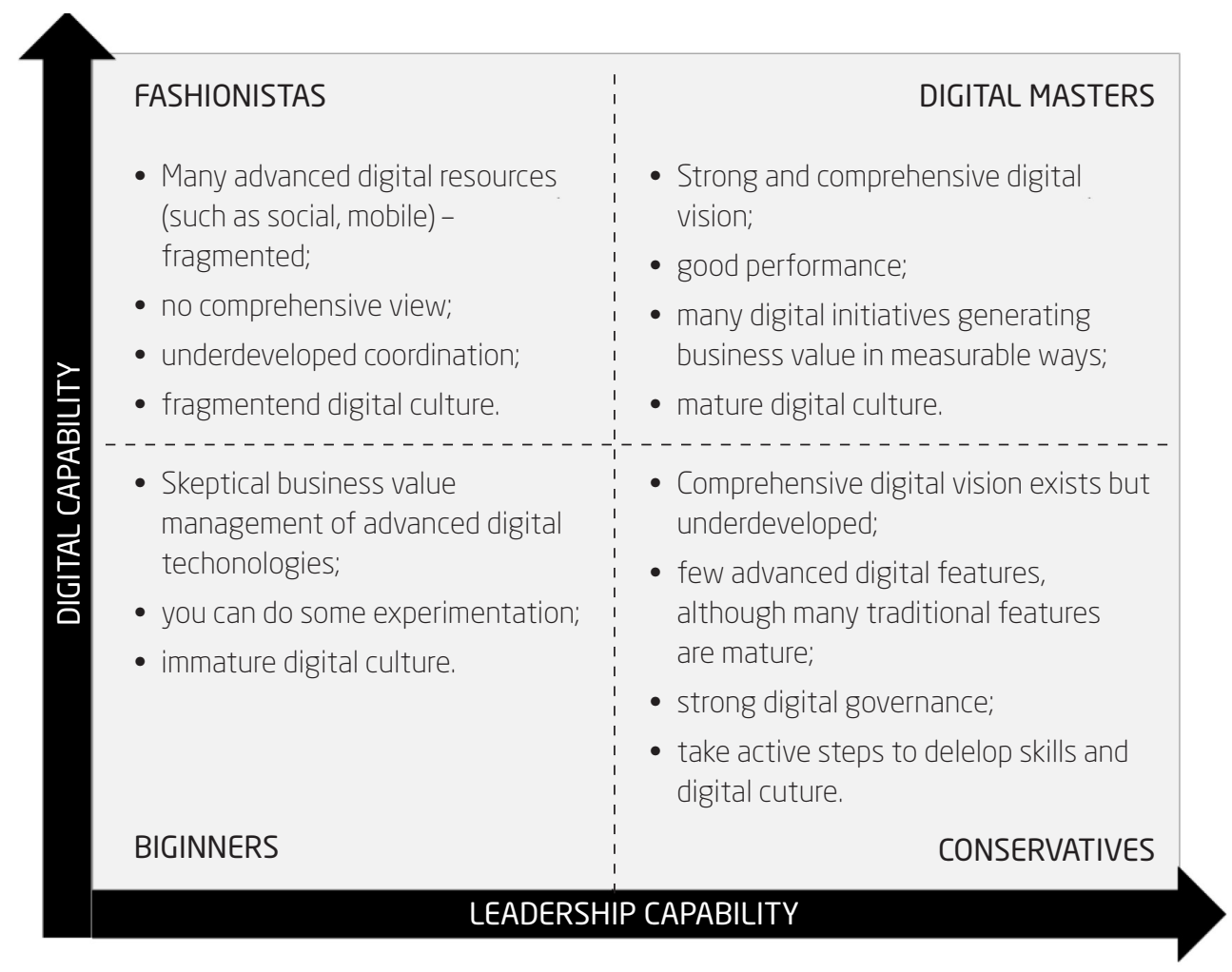

Source: Westerman et al. (2011, p. 60).

Figure 3.4 shows that the inclusion in the graph of the results of the analysis of each of the HEI in the axes "leadership capability" and "digital capability" resulted in the classification in one of the four levels of digital mastery defined by Westerman et al. (2016): beginners, fashionistas, conservatives, and digital masters, named:

- Beginners: those who are at the beginning of their digital journey and often conduct benchmarking tests before taking steps to ensure what they are doing. They are usually inertial or resistant to change. 
- Fashionistas: those who invest in technology, implement it, but do not change their internal processes, governance, and leadership capacity. They often lose investments and tend to act impulsively.

- Conservatives: compared to fashionistas, they are those who have a history of empowerment, but their extreme caution prevents them from investing in and developing reliable digital resources. Many rules of governance can guarantee order but impede progress.

- Digital masters: those who have overcome difficulties. They know what it is important to invest in to support the company, in what order each technology will appear, and what problems will arise. They link investments to digital transformation plans and generate new services and products from the use of technology.

At the end of the assessment, it was possible to clearly see the scenario in which each of the analyzed HEI is positioned in relation to digital mastery and, above all, to the digital transformation process.

\section{RESULTS AND ANALYSIS}

When analyzing the IT tools and processes currently implemented in the HEI, the names of the systems, Wi-Fi, network, tickets, portal, platform, and most critical modules were all present. Interestingly, the two HEI that stood out in this regard were both medium-sized (HEI-03-M and HEI-05-M).

This fact would need to be further explored because large HEI mix their processes with unique and often world-class tools, while smaller HEI generally devote more energy to emerging tools (e.g., startups) due to budget constraints and cloud-based technologies, because they are faster to implement and do not generate internal infrastructure costs. According to the Research Protocol, the technologies used by each of the HEI under study were determined in some of the sectors analyzed (e.g., in the academic system, in the library, in the student portal, in the business management system, and others), which are listed in Figure 4.1. 


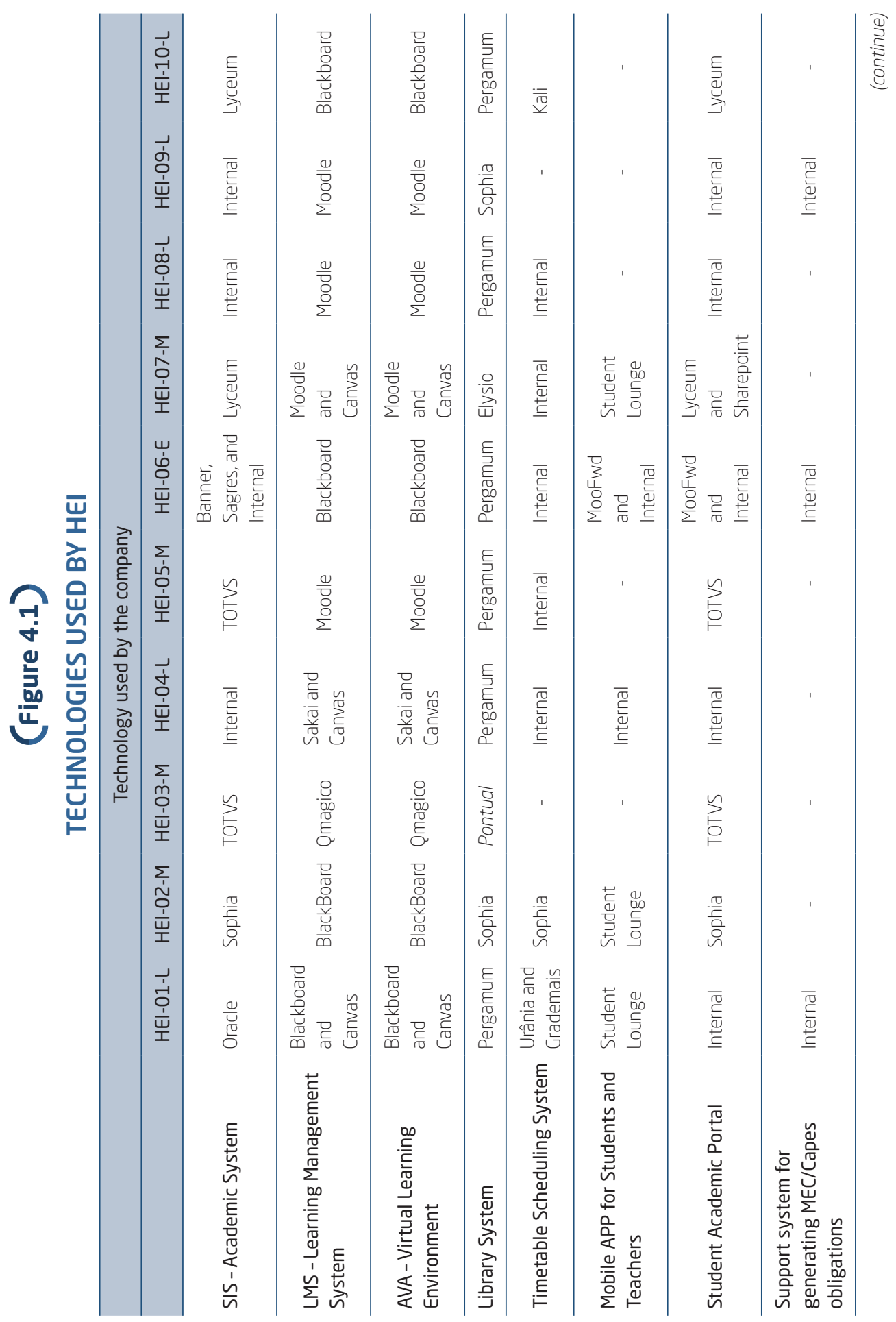




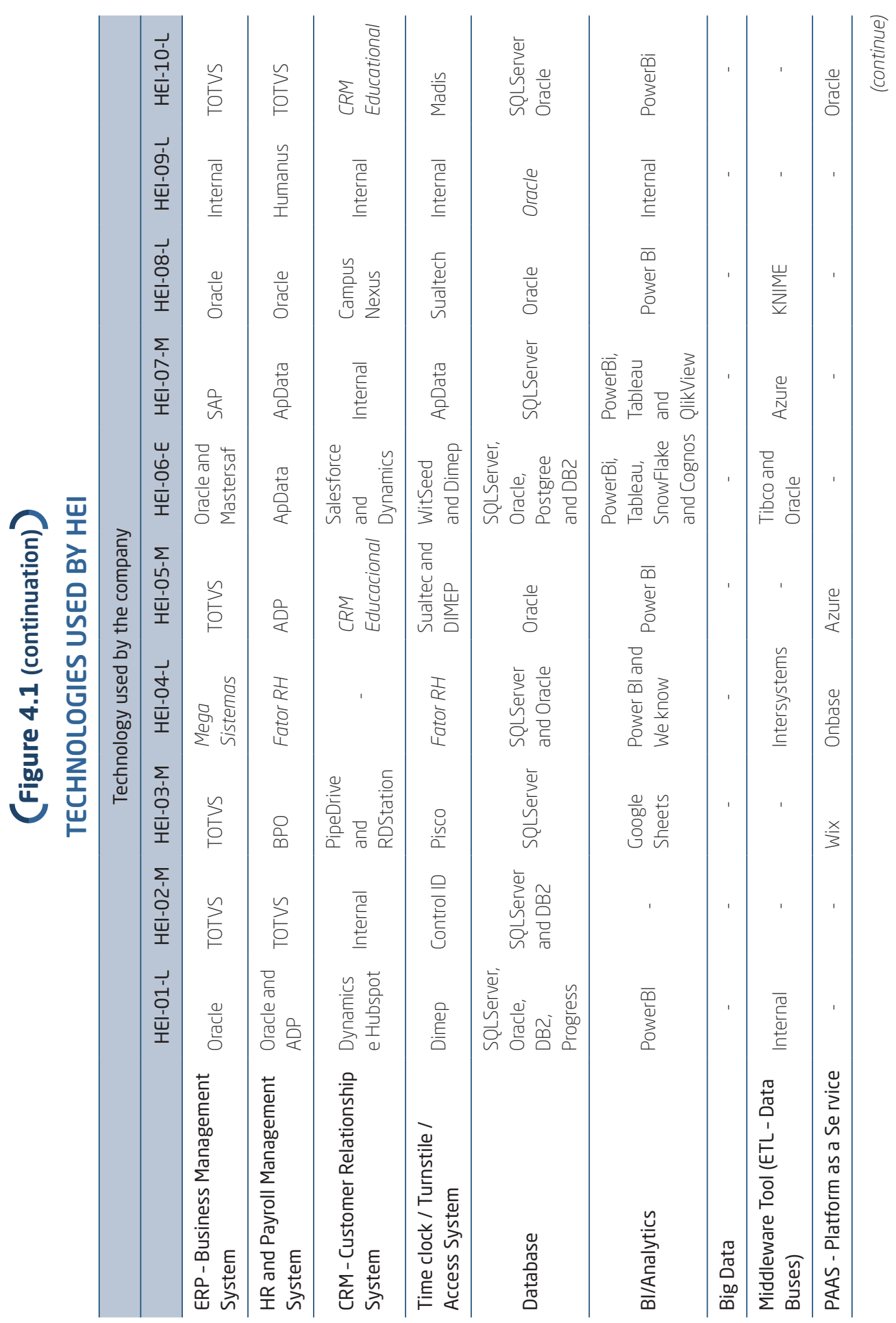


Francisco D. S. Luna, Vivaldo J. Breternitz

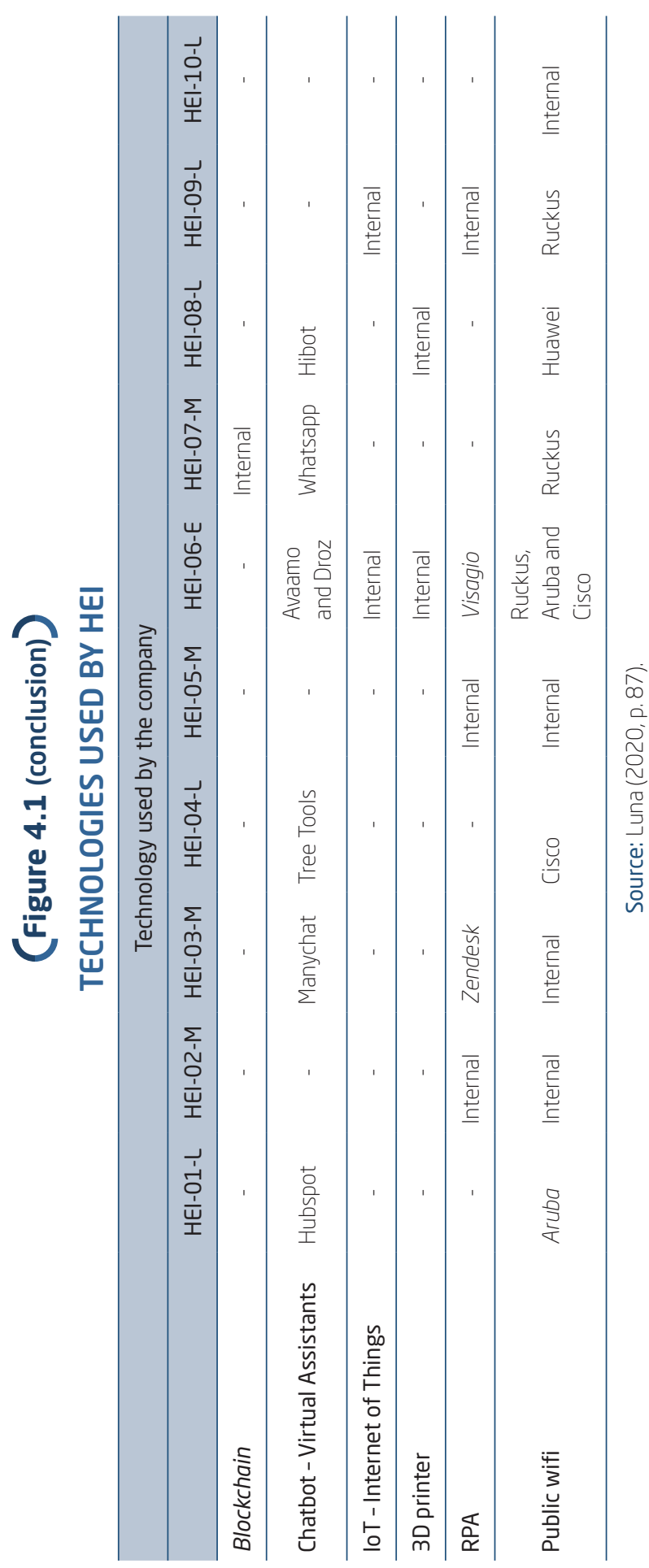


In this part of the analysis, "market system" and "market tool" is the denomination for solutions developed by a national or international software provider. The nomination "Internal" was chosen to designate a solution developed by the HEI's IT Team.

According to data presented in Figure 4.1, it is possible to establish the following weightings: as for the Academic Systems in the market, they are widely used by the HEI, being present in seven of the ten HEI in the sample, especially: Oracle, Sophia, TOTVS, Banner, Sagres, and Lyceum. Only three HEI use internal systems.

As for the learning management systems in the market (LMS and AVA), they are used by all researched HEI, with a predominance of Blackboard and Moodle.

As for library systems, all analyzed HEI use market systems, with Pergamum being the most frequent, present in six HEI.

As for the timetable scheduling, no standard type was identified, as it is a process that depends on criteria that vary for each HEI. Three HEI use market solutions (Urânia, Grademais, Sophia, and Kali), five use internal solutions and two have a completely manual timetable. Mobile apps for students and teachers are present in half of the sample, with three HEI using market mobile Apps (Student Lounge and MooFwd), one HEI using an internal solution, and one HEI using one internal and one from the market.

As for the student portal, six HEI use market portals (Sophia, TOTVS, MooFwd, Lyceum, and Sharepoint), and four use internal portals.

As for the delivery of documentation to Ministério da Educação (MEC) and to Coordenação de Aperfeiçoamento de Pessoal de Nível Superior (Capes), three HEI were identified that use some type of systemic control, all of them with homemade solutions.

As for the control system for financial, purchasing, and administrative processes (ERP), nine of the ten HEI surveyed use a market system (Oracle, TOTVS, Mega Sistemas, Mastersaf, and SAP), only one of them is an exception, as it developed and continues to improve its ERP internally, believing it to be the best approach for its reality.

As for the people and payroll management system, nine HEI use a market tool (Oracle, ADP, TOTVS, FatorRH, ApData, and Humanus), while only one of them uses a service provider for this process, the model called BPO.

Regarding the tools for customer relationship management (CRM), there was little standardization. Three HEI use internal tools, six HEI use market tools (Dynamics and Hubspot; PipeDrive and RDStation; Educational CRM; Salesforce and Dynamics; Campus Nexus), and only one claimed not to have a tool for this purpose. 
Nine HEI use market systems to manage Time Clocks, Turnstiles, and Accesses (Dimep, Control ID, Pisco, Fator RH, Sualtec and DIMEP, WitSeed and Dimep, ApData, Sualtech, and Madis), only one has developed a tool for this purpose.

All HEI analyzed use market database management systems, including SQLServer, Oracle, DB2, Progress, and Postgree, and the most used ones are Oracle and SQL Server. It was found that, in half of the sample, HEI use more than one database.

Specifically, for BI/Analytics, eight HEI use market tools (PowerBI, Google Sheets, We know, Tableau, SnowFlake, Cognos, and QlikView). One institution uses an internal tool, and one does not have any tool.

None of the HEI presented preparation for Big Data, and only two institutions mentioned that they are structuring Data Lakes to use data for business intelligence.

Four institutions use market middleware tools (Intersystems, Tibco and Oracle, Azure, and KNIME) to manage their integrations, and only one developed its middleware internally. The others do not have any (three of these are medium-sized).

The precarious use of the concept of Platform as a Service was found, with only four adherents (Wix, OnBase, Azure, and Oracle) and with low usage. Only one institution has an internal initiative for Blockchain.

As for ChatBot, six Institutions use seven different market tools (Hubspot, Manychat, Tree Tools, Avaamo and Droz, Whatsapp, and Hibot). Only two presented something related to IoT (internet of things) and, even then, only internally. Two HEI use 3D printers with internal systems.

Regarding process automation via robots (RPA), five initiatives were verified, two with market platforms (Zendesk and Visagio) and three with internal systems.

Regarding Wi-Fi available for public use, all HEI have it, and all have expressed concerns about the expectations of students. Six use hardware and design with market companies (Ruckus, in three HEI; Cisco and Aruba, in two HEI; and Huawei, in one HEI), while four bought the hardware and implemented it on their own.

In the sample, a bias towards the adoption of market tools to the detriment of internal systems was clearly observed.

Figure 4.2 complements the information in Figure 4.1, indicating the sectors of the HEI analyzed where internal, market tools or no tools were inserted, clearly demonstrating where a greater incidence of the digital transformation process can be seen. 


\section{(Figure 4.2)}

MARKET TOOLS VERSUS INTERNAL DEVELOPMENT

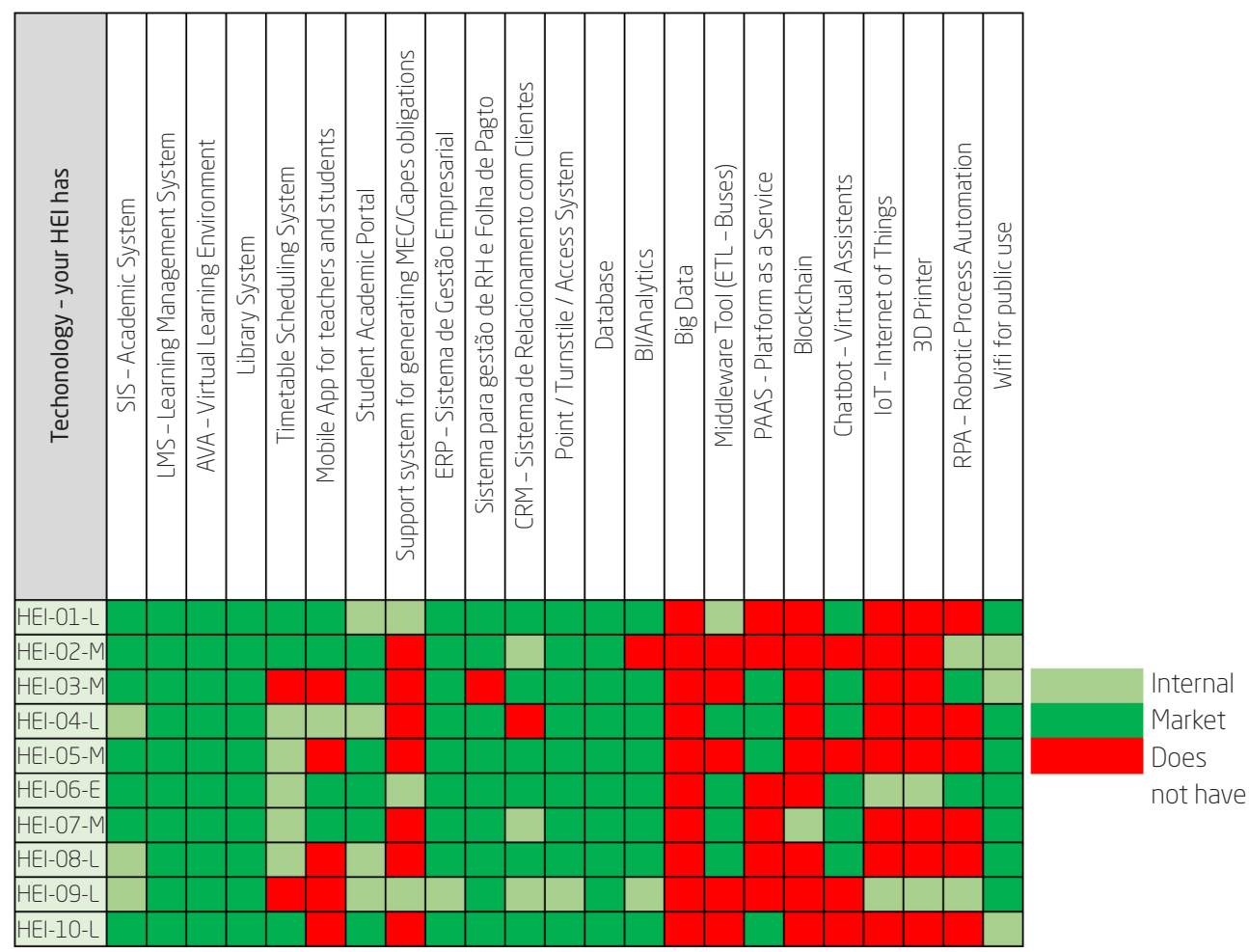

Source: Luna (2020, p. 91).

From the synthesis presented in Figure 4.2, it was possible to verify that, referring to the student information system (SIS), all the HEI analyzed use technology tools, with only three using an internal solution, which demonstrates advances in their digital transformation processes. The motivations for adopting market tools are as follows:

1) Frequent changes in laws and guidelines established by official bodies generate costs and great efforts, so that institutions are always up-todate.

2) Market tools receive maintenance and updates to their technological platform frequently, which is seen as a benefit by the HEI, as they will be able to remain refreshed and secure, updating their systems versions frequently. 
3) By taking on the roadmap of a company specialized in systems, HEI can turn all their energy to the company's core business, which is education.

4) Market tools bring the best market practices "embedded" with their solutions, given that the evolution of systems has as its starting point customer requests and feedback.

5) With market systems for operational functions, the HEI' IT departments can focus on analyzing data (business intelligence) rather than developing solutions.

Bianchi et al. (2017) made six recommendations to add mechanisms to the existing IT governance in HEI. Among them, the fifth point presents suggestions regarding the use of tools common to other HEI, pointing out the benefits of exchanging information and reducing costs from this practice. Rodrigues (2021, p. 68 , our translation) also reinforces the recommendation for adapting to market standards and treating the digitization of teaching means as vital:

Higher education professors almost have an obligation to follow evolution and innovation, and this will also bring other means so that they can change, modify, introduce novelties in what they do and be in line with the market, which means that the environment of innovation, talent creation, and knowledge creation needs to be nurtured.

Only one of the HEI is adept to internally developed systems (HEI-09-L). In Figure 4.2, according to the information provided by the manager of this institution, it can be seen that of the 23 technologies evaluated, ten use internal systems. The manager affirms that the HEI is fully satisfied with these technologies, and the internal team has no difficulties with the customization and development required by the law.

As a way to consolidate and compare the HEI's digital transformation journey, each one of them was individually assessed through a digital mastery self-assessment model (Westerman et al., 2011, 2016) based on the interviews. The results obtained were compiled in Figure 4.3. 


\section{(Figure 4.3)}

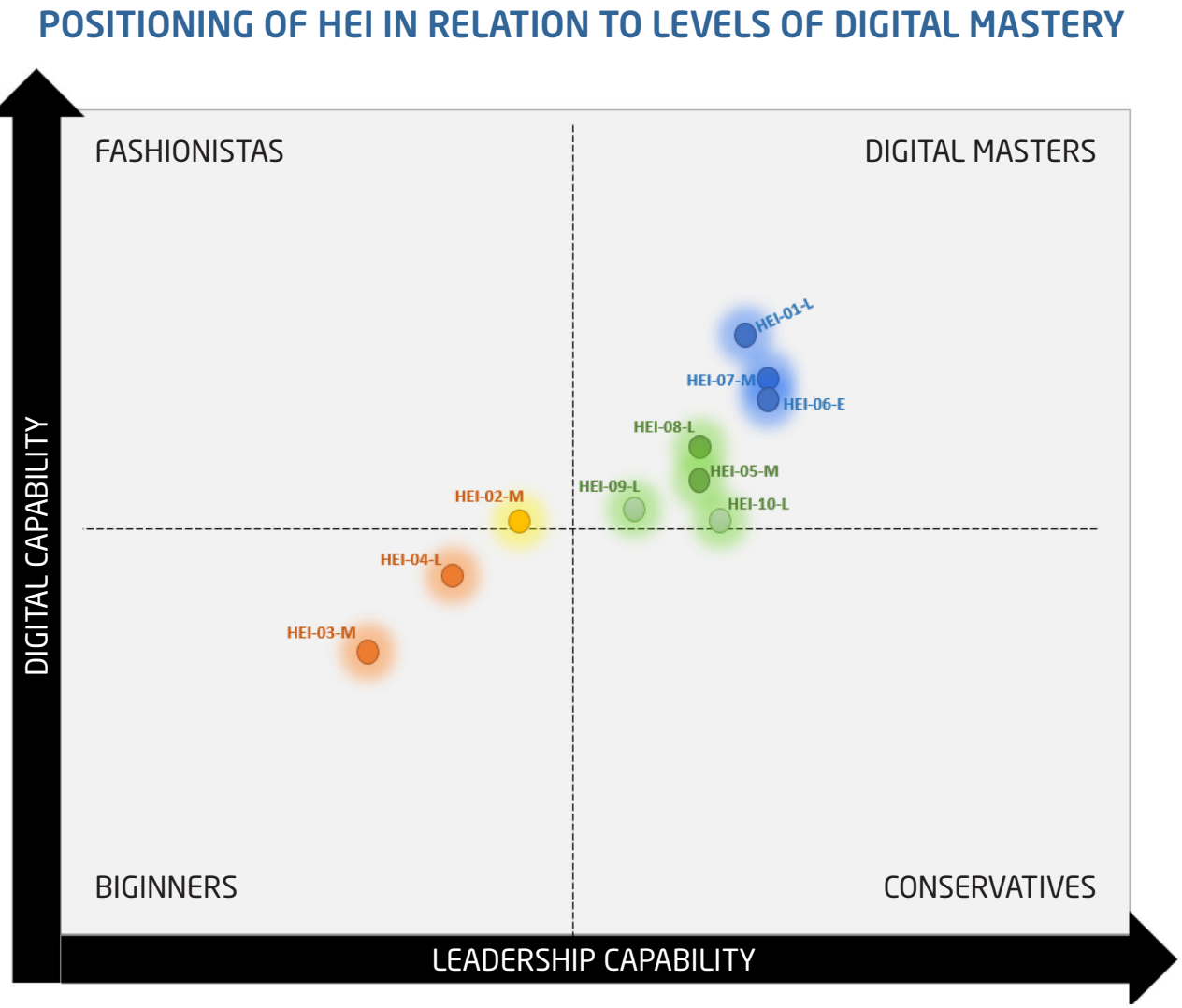

Source: Luna (2020, p. 104)

The research carried out by Westerman et al. (2011), which found a percentage of $20 \%$ of digital masters, did not consider companies in the education market in their sample. However, the result of this research allowed us to verify that $70 \%$ of the institutions evaluated fit the classification of digital masters, some more prominently, others in a borderline area. Thus, when comparing the results, and also reinforcing the fact that this research is not quantitative, two questions were raised for reflection:

1) Is the education segment more technological than the others?

As shown in Figure 4.3, given the characteristics of the B2C market, with many customers, the higher education market is highly computerized, and the use of distance learning technology platforms is also growing, which can provide support for a comparative basis, demonstrating advantages in 
the field of higher education. Despite the results obtained, it is noteworthy that the limitations of the sample can cause distortions of reality in relation to other parts of Brazil, as nine of the ten HEI analyzed are located in São Paulo and also because small institutions were not evaluated, which certainly would add other points of view.

2) Does the questionnaire not apply to the educational sector, or did the world as a whole mature between 2011 and 2019?

The study by Westerman et al. (2011) was carried out a few years ago; it is, of course, conceivable that the whole world has developed since then. However, the questionnaire was not considered inappropriate for the area of education, but care should be taken when evaluating the results, noting the characteristics of the sample.

As a way of deepening the analysis, four clusters were defined, grouped according to their position in the graph: blue, green, yellow, and red, as seen in Figure 4.3.

\subsection{Blue cluster}

This group is formed by the HEI that obtained the best results in the research sample. They are institutions with high digital capacity and high leadership capacity. From the authors' point of view, the recommendations for them are: to better document the digital transformation process and to create more formal control means (committees) to monitor the development of this field (indicators).

\subsection{Green cluster}

This group is formed by HEI above the breakeven point, but if they want to continue growing, some issues need to be observed. These are institutions with evolving digital capabilities and well-structured leadership skills. A characteristic of these HEI is the inconsistency between the plan and the technical implementation. Sometimes, it was possible to see in the interviews that the technology had already been implemented, but there was no proper management or even measurement of the results obtained. Furthermore, these technologies can be implemented over time without integration with other systems, meaning that the scope was limited. From the authors' point of view, the recommendations for them are: to review the mission and guidelines of the digital transformation process and to devote more time to planning the implementation of technologies of greater value to users. 


\subsection{Yellow cluster}

This group is composed entirely of HEI-02-M. They are HEI with growing digital capabilities and limited leadership capabilities. From the authors' point of view the recommendations are: to elaborate specific plans for the digital transformation, define goals and indicators, and seek investments in existing technologies that help improve performance.

\subsection{Red cluster}

This group is formed by the HEI that received the worst ratings. These institutions are still struggling to develop their digital capabilities and are trying to justify their investments with the board of directors. These HEI have limited leadership capabilities and lack direction in terms of the technology's impact on their future. From the authors' point of view, the recommendations for them are: to review their internal processes to find digital opportunities; to develop a plan for the journey of digital transformation; and to seek their internal leaders for contemporary agile management models and/or startup models.

Scientific studies that directly relate the increase in academic performance with advances in the digital transformation of a given institution were not identified, thus, outlining a gap to be studied in future work. In any case, as confirmed by Kenski et al. (2019) and Araújo and Gouveia (2020), there is a consensus that the evolution of processes improves the quality of the HEI in general, as it facilitates the process of students' access to the services of the HEI and the dynamics of classes through digital tools that bring new learning possibilities. Such positions are connected with the survey conducted, in which respondents, at various times, considered technology as vital to the success of the HEI.

\section{FINAL CONSIDERATIONS}

This work started from the question: "Are Brazilian private HEI prepared in their digital transformation process and, consequently, have the IT tools and processes that help them to achieve the results, or does their lack of preparation inhibit their growth?". Through the analysis of the sample data, it was found that the evaluated HEI have a good level of digitization. Some data that confirmed this conclusion were: all analyzed HEI have market management systems (LMS and AVA); all have library systems; all of them 
have a control system for financial, purchasing, and administrative processes (ERP), with nine of them having market systems and only one has an internal system, believing it to be the best for their reality; all have a people management system and payroll (nine HEI use a market tool, and only one of them uses a service provider for this process); all use market database management systems, with half of them using more than one database; and all provide Wi-Fi for public use.

Therefore, data analysis confirmed that the analyzed Brazilian private HEI somehow planned their journey of digital transformation. Still, they have certain limitations in the development of digital capabilities and in the development of leadership capabilities. The assessment results of digital mastery brought something interesting: of the ten institutions surveyed, seven are in the "digital master" quadrant. That is, they know where they are positioned and are preparing for the future.

Furthermore, it was discovered was that the institutions studied understood the value of the data-based decision-making process. As mentioned earlier, they have a system matrix that covers their main processes, and nine out of ten use some sort of indicators system. Furthermore, the HEI value integrating their systems and believe that expanding the use of disruptive technologies such as artificial intelligence, mobility, and IoT will help improve the user experience with their solutions. As mentioned earlier, drivers and enablers are responses to the company's strategic objectives, in this case, becoming system requirements.

It should be noted that the results of this study were obtained sometime before the onset of the Covid-19 pandemic. Given the situation outlined by the quarantine and the urgent need to insert new collaboration tools, communication work, and remote access via VPN, HEI in Brazil may need to look for other solutions and faster development.

\section{TRANSFORMAÇÃO DIGITAL EM INSTITUIÇÕES DE ENSINO SUPERIOR PRIVADAS BRASILEIRAS: LINHA DE BASE PRÉ-CORONAVÍRUS}

\section{RESUMO}

Objetivo: Apresentar o planejamento para a transformação digital de em instituições de ensino superior (IES) brasileiras e medir seu grau de 
maestria digital, conforme o modelo proposto por Westerman, Calméjane, Bonnet, Ferraris e McAfee (2011).

Originalidade/valor: Existem estudos que avaliam a transformação digital e/ou o grau de maestria digital em IES individualmente, entretanto não foram identificados os que os avaliam comparativamente, permitindo traçar uma linha de base para auxiliar gestores em processos de benchmarking. Design/metodologia/abordagem: Trata-se de uma pesquisa exploratória, qualitativa, com estudo de campo, na qual os dados secundários foram obtidos por meio de fontes bibliográficas e documentais e os primários por meio de entrevistas semiestruturadas. Para tanto, foram entrevistados representantes de dez IES privadas, utilizando-se um instrumento desenvolvido, composto por um roteiro de perguntas. O conteúdo foi analisado conforme modelo de Bardin (2011) e apoiado pela ferramenta Iramuteq. Os achados serviram de insumo para preenchimento dos questionários de maestria digital.

Resultados: Elementos identificados na pesquisa remetem ao fato de que as IES avaliadas possuem boa maturidade em seu processo de transformação digital. Tais alegações puderam ser constatadas a partir da avaliação da maestria digital, que constatou que a maioria das instituições têm um bom nível de digitalização e que, apesar de conviverem com algumas limitações referentes ao desenvolvimento de capacidades digitais e de liderança, podem ser consideradas mestres digitais.

\section{PALAVRAS-CHAVE}

Transformação digital. Instituição de ensino superior. Maestria digital. Governança de TI. Tecnologia.

\section{$\int$ REFERENCES}

Araújo, A. C. M., \& Gouveia, L. B. (2020). Utilização e importância das TICs em uma instituição de ensino superior (IES) da cidade de Belém do Pará: Perspectivas da equipe pedagógica, coordenadores de curso, professores e alunos da graduação. Brazilian Journal of Development, 6(8), 63757-63777. 
Associação Brasileira das Empresas de Software (2017). Mercado brasileiro de software: Panorama e tendências. São Paulo: Abes. Retrieved from https:// abessoftware.com.br/wp-content/uploads/anterior/Arquivos/Dados\%20 2011/ABES-Publicacao-Mercado-2017.pdf

Bardin, L. (2011). Análise de conteúdo. São Paulo: Edições 70.

Bianchi, I. S., Sousa, R. D., \& Pereira, R. (2017). IT governance mechanisms at universities: an exploratory study. Strategic and Competitive Use of Information Technology (SCUIT). Boston, Twenty-third Americas Conference on Information Systems, 1-10.

Bridgstock, R. (2016). Educating for digital futures: What the learning strategies of digital media professionals can teach higher education. Innovations in Education and Teaching International, 53 (3), 306-315.

Brodbeck, A., \& Musse, J. (2014). Práticas de governança de tecnologia de informação em universidades da América Latina. Conferencia de Directores de Tecnología (TICAL), 4, Cancún.

Carvalho, R. (2017). Nova regulamentação do MEC para EAD. Edools. Retrieved from http://www.edools.com/nova-regulamentacao-domec-para- ead/

Davel, R. (2018). Estratégias de sobrevivência para as pequenas e médias instituições. Revista Ensino Superior, edição 227. Retrieved from https:// revistaensinosuperior.com.br/sobrevivencia-instituicoes/

Decreto n. 9.057, de 25 de maio de 2017 (2017). Retrieved from http://pesquisa. in.gov.br/imprensa/jsp/visualiza/index.jsp?data $=26 / 05 / 2017 \&$ jornal $=1$ \&pagina $=4 \&$ totalArquivos $=240$

Harvard Business Review Analytics Services (2015). The digital transformation of business. Harvard Business Review, (149), 1-6. Retrieved from https:// hbr.org/resources/pdfs/comm/microsoft/the_digital_transformation_of_ business.pdf

Hoper (2018). Webinar: Configurações do mercado educacional brasileiro e as EdTechs. Retrieved from https://assets.eventials.com/1df7dfe 55fcc4d8 eab81bdef31dcfd07/ Webinar_Hoper_EdTechs.pdf

Information Systems Audit and Control Association (s. d. (a)). Purpose and promise. Retrieved from https://www.isaca.org/why-isaca/about-us/ purpose-and-strategy

Information Systems Audit and Control Association (s. d. (b)). Frameworks, standards and models. Retrieved from https://www.isaca.org/ resources/ frameworks-standards-and-models 
Initiative for Digital Transformation (2015). Survey 2015. Skills for digital transformation. Retrieved from https://www.i17.in.tum.de/fileadmin/ w00btn/www/IDT_Skill_Report_2015.pdf

Instituto Brasileiro de Geografia e Estatística (2019). Pesquisa de orçamentos familiares 2017-2018: Primeiros resultados. Rio de Janeiro: IBGE. Retrieved from https://biblioteca.ibge.gov.br/visualizacao/livros/liv 101670.pdf

Instituto Brasileiro de Geografia e Estatística (2020). Séries históricas do PIB. Recuperado em de https://www.ibge.gov.br/estatisticas/economicas/ contas-nacionais/9300-contas-nacionais-trimestrais.html $=\& \mathrm{t}=$ serieshistoricas\&utm_source=land ing\&utm_medium $=$ explica\&utm_campaign = pib\#evolucao-taxa

Instituto Nacional de Estudos e Pesquisas Educacionais Anísio Teixeira (2009). Resumo técnico: Censo da Educação Superior de 2009. Retrieved from http://download.inep.gov.br/download/superior/censo/2009/ resumo_tecnico_2009.pdf

Instituto Nacional de Estudos e Pesquisas Educacionais Anísio Teixeira (2020). Censo da Educação Superior. Retrieved from http://portal.inep. gov.br/web/guest/censo-da-educacao-superior

Iramuteq (2020). Interface de R pour les Analyses Multidimensionnelles de Textes et de Questionnaires. Retrieved from http://iramuteq.org/

Kenski, V. M., Medeiros, R. A., \& Ordéas, J. (2019). Ensino superior em tempos mediados pelas tecnologias digitais. Trabalho E Educação, 28(1), 141-152.

Khalid, J., Ram, B. R., Soliman, M., Ali, A. J., Khaleel, M., \& Islam, M.S. (2018). Promising digital university: A pivotal need for higher education transformation. International Journal of Management in Education, 12(3), 264-275.

Koike, B. (2018). Receita menor com FIES afeta setor privado. Valor Econômico. Retrieved from https://www.valor.com.br/empresas/5521747/receitamenor-com-fies-afeta-setor-privado

Luna, F. D. S. (2020). Instituições de ensino superior brasileiras e sua jornada para a transformaçãa digital (Dissertação de mestrado, Universidade de São Paulo, São Paulo, Brasil). doi:10.11606/D.12.2020.tde-15102020-154313

Mansur, R. (2007). Governança de TI: Metodologia, frameworks e melhores práticas. Rio de Janeiro: Brasport.

McKinsey (2016). Mastering the enablers of a sustained digital journey. Retrieved from https://www.mckinsey.com/ /media/McKinsey/ 
Industries/Consumer\%20Packaged\%20Goods/Our\%20Insights/Mastering \%20the\%20enablers\%20of\%20a\%20sustained\%20digital\%20journey/ Mastering-the-enablers-of-a-sustained-digital-journey.ashx

Palhares, I. (2018). Crise impulsiona matrículas em cursos de ensino a distância. O Estado de S. Paulo. Retrieved from https://educacao.estadao.com. br/noticias/geral,crise-impulsiona-matriculas-em-cursos-do-ensino-adistancia,70002511974

Rodrigues, A. A. B. (2019). A transformação digital no ensino superior: Obrigação? Opção? Oportunidade? Conferência FORGES, 9, 1-388.

Rodrigues, S. C. (2021). A transformação digital nas instituições de ensino superior: Um estudo de caso (Dissertação de mestrado, Instituto Superior de Contabilidade e Administração do Porto, Portugal).

Rogers, D. L. (2017). Transformação digital: Repensando o seu negócio para a era digital. São Paulo: Autêntica Business.

Santinello, J., Costa, M. L. F., \& Santos, R. O. D. (2020). A virtualização do ensino superior: Reflexões sobre políticas públicas e educação híbrida. Educar em Revista, 36, 1-19.

Schwab, K. (2016). A Quarta Revolução Industrial. São Paulo: Edipro.

Susskind, R., \& Susskind, D. (2015). The future of the professions. Oxford: Oxford University Press.

Westerman, G., Bonnet, D., \& McAfee, A. (2016). Liderando na era digital. São Paulo: M.Books.

Westerman, G., Calméjane, C., Bonnet, D., Ferraris, P., \& McAfee, A. (2011). Digital transformation: A roadmap for billion-dollar organizations. Retrieved from https://www.capgemini.com/wp-content/uploads/ 2017/07/Digital_Transformation__A_ Road-Map_for_Billion-Dollar_ Organizations.pdf

World Economic Forum (2015). Technology tipping points and societal impact. Retrieved from http://www3.weforum.org/docs/WEF_GAC15_ Technological_Tipping_Points_report_2015.pdf

\section{AUTHOR NOTES}

Francisco D. S. Luna, master from the Faculty of Economics, Administration, Accounting and Actuarial (FEA), University of São Paulo (USP); Vivaldo J. Breternitz, Ph.D. from (FEA), UUSP. 
Francisco D. S. Luna is now na alumnus at USP and Consulting Services Director; Vivaldo J. Breternitz is now coordinator at the Faculty of Computing and Informatics of Mackenzie Presbyterian University (UPM).

Correspondence concerning this article should be addressed to Francisco D. S. Luna, Avenida Professor Luciano Gualberto, 908, Butantã, São Paulo, São Paulo, Brazil, CEP 05508-010.

\section{EDITORIAL BOARD}

Editor-in-chief

Gilberto Perez

Associate editor

Rodrigo Baroni de Carvalho

Technical support

Vitória Batista Santos Silva

\section{EDITORIAL PRODUCTION}

Publishing coordination

Jéssica Dametta

Language editor

Daniel de Almeida Leão

Layout designer

Emap

Graphic designer

Libro 